\title{
The Effect of Pharmaceutical Patent Term Length on R\&D and Drug Expenditures in Canada
}

\author{
L'effet de la durée des brevets pharmaceutiques sur les \\ dépenses en $R \& D$ et en médicaments au Canada
}

\author{
by BOHUMÍR PAZDERKA, PHD \\ School of Business, Queen's University \\ Kingston, $\mathrm{ON}$
}

\begin{abstract}
The authors make a useful and original contribution to evaluating the impact of strengthened patent protection of pharmaceuticals on Canadian healthcare expenditures. This commentary argues that their second task - measuring the impact of strengthened patent protection on R\&D spending in Canada - faces an insurmountable conceptual problem: Corporate decisions on the location of R\&D activities bear no theoretical relationship to the location of sources of $R \& D$ funding and are guided by other factors, including political considerations.
\end{abstract}

\section{Résumé}

Les auteurs font une contribution utile et originale à l'évaluation de l'incidence d'une protection accrue des brevets pharmaceutiques sur les dépenses en soins de santé 
au Canada. Ce commentaire soutient que leur seconde tâche - mesurer l'incidence d'une protection accrue des brevets sur les dépenses en R\&D au Canada - se heurte à un obstacle conceptuel insurmontable, à savoir, les décisions des grandes entreprises quant à l'endroit où se déroulent les activités de $R \& D$ n'ont aucune relation théorique à l'emplacement des sources de financement pour la R\&D et sont guidées par d'autres facteurs, dont des considérations d'ordre politique.

\section{Che objective of Grootendorst and Di Matteós study is two- fold: first, to evaluate the contribution of the strengthened Canadian pat- Lent protection of pharmaceutical innovation to $R \& D$ spending in Canada,} and second, to determine its impact on drug prices and thus on healthcare spending. This commentary argues that while the latter is a useful and worthwhile exercise, the former is an impossible task.

\section{The tenuous link between domestic patent protection and domestic $R \& D$ spending}

Stronger patent protection increases the profits available to the innovator for increased $R \& D$ spending anywhere in the world. The total contribution to global $R \& D$ effort made in the form of increased profits (patent rents) collected from Canadian users of prescription drugs can, in principle, be greater or smaller than the extra R\&D spending in Canada. The authors explicitly recognize that the multinationals have "discretion over the location of $R \& D$ " and that, therefore, the relevant objective would be to assess the impact on global R\&D. Yet they assert that they "estimated the effect ... on ... expenditure on Canadian pharmaceutical R\&D."

Global pharmaceutical innovation is financed primarily from the extra profits (rents) generated by patent holders, and to a lesser extent by public funds. The contribution each country makes to the financing of global innovation is therefore largely a function of the strength of its patent system. Until the TRIPS agreement came into force (on January 1,1995), the strength of patent protection was determined by national authorities and varied across countries. ${ }^{1}$ The TRIPS agreement made a minimum standard of contribution mandatory; those countries that previously contributed less joined TRIPS because it was a condition of membership in the Word Trade Organization. ${ }^{2}$

The location of $\mathrm{R} \& \mathrm{D}$ activity (or $\mathrm{R} \& \mathrm{D}$ spending), as distinct from the location of the sources of financing, is a function of private decision-making by the management of the (multinational) drug companies. For example, a typical Swiss drug corporation 
locates much of its R\&D activity in the home country, but collects well over half of its rents in the US market, while most of the rest comes from countries other than Switzerland. ${ }^{3}$ Indeed, the Swiss patent legislation was historically relatively weak; for example, until 1978 only pharmaceutical process, but not product, could be patented (Schiff 1971; Zutshi 1998: 41). The determinants of location of pharmaceutical R\&D activity listed in the literature typically include historical factors, availability and cost of skilled personnel, proximity to centres of academic research and to clinical testing facilities, and government incentives, such as the tax treatment of $R \& D$ expenditures.

\section{Controls on prescription drug spending}

With patent protection more or less uniform in the post-TRIPS world, ${ }^{4}$ attention has focused on policies and practices seeking to control prices or influence the selection of prescribed drugs and thus reduce the burden of prescription drug spending.

\section{... a similar role is performed by private sector players, such as the health insurance industry or pharmaceutical benefits management companies.} Specifics include encouragement of generic prescribing; promulgation of formularies that restrict reimbursement for certain (high-priced) drugs, making the percentage of a drug's reimbursement conditional on independent evaluation of its therapeutic efficiency; and influencing physician prescribing behaviour (Grootendorst and Di Matteo briefly list the Canadian programs in their paper; those of other countries are reviewed in Jacobzone 2000).

The authors controlled for the impact of these policies by reference to drug price inflation and per capita drug expenditure in the United States, on the grounds that the United States "has not introduced drug price regulation." It should be noted, however, that a similar role is performed by private sector players, such as the health insurance industry or pharmaceutical benefits management companies. US drug prices and per capita drug expenditures have therefore not increased as much as would be the case with "unrestricted" patent protection.

\section{R\&D spending trends}

The R\&D-to-sales ratio in the Canadian pharmaceutical industry, both during the latter part of the period covered by the study and during the post-study period, has been declining, although the stronger patent protection remains in place. It reached its peak 
of $11.7 \%$ in 1995 and declined to a low of $8.3 \%$ in 2004 before rising (marginally) to $8.7 \%$ in 2005 . The absolute value of $\mathrm{R} \& \mathrm{D}$ expenditures (in current dollars) increased in all years during the period since 1988, except for 2003 and 2004, when it dropped by $0.4 \%$ and $2 \%$, respectively (PMPRB $2006: 39$ ).

In contrast, the $\mathrm{R} \& \mathrm{D}$-to-sales ratios of the US-based companies, members of the Pharmaceutical Research and Manufacturers of America (PhRMA), have been much more stable: the ratio of domestic (US) R\&D to global sales was $13.1 \%$ in 1995, rose to $14.0 \%$ in 1997 and dropped to a minimum of $12.2 \%$ in 2004 before rising to an estimated $12.6 \%$ in 2005 . The ratio of $\mathrm{R} \& \mathrm{D}$ spending abroad to global sales over the same period fluctuated within the range of $2.8 \%$ to $3.6 \%$, with no apparent trend (calculated from data in PhRMA 2006: 52, 57).

\section{Conclusion}

The authors have made a sophisticated attempt at evaluating the extra contribution Canadian consumers are making to global pharmaceutical innovation as a result of the 1987 and 2003 modifications of the Patent Act. Given the data problems, their results have to be qualified; however, theirs is an imaginative and useful effort. On the other hand, while the strength of a national patent system determines the contribution of a country's consumers to global innovation, it has no necessary relationship to the size of the R\&D activity on its territory. The "bulge" in the pharmaceutical R\&D-to-sales ratio in Canada, which occurred after 1987 and peaked in 1995, has to be explained by other factors. The allusion the authors make to the "discretion" the multinationals have, to the "negotiations that resulted in patent terms being extended" and to the political commitment made by the Pharmaceutical Manufacturers Association of Canada should have been given more prominence than they received in the paper. (Incidentally, the PMAC commitment to a $10 \%$ R $\&$ D-to-sales ratio has not been kept since 2001.)

Correspondence may be directed to: Bohumír Pazderka, School of Business, Queen's University, Kingston, ON. E-mail: BPazderka@business.queensu.ca.

\section{NOTES}

1. International comparison of the strength of patent protection (in general, not just in pharmaceuticals) gives considerable support to the "exploitation hypothesis" from the theory of alliances: when the size of the contribution is determined by national governments, smaller (or poorer) countries exploit the larger (or richer) ones, in the sense that the larger (richer) countries provide disproportionately larger contributions to the financing of innovation (Ginarte and Park 1997: 285, 291; Park 2001: 110-11). 
2. This link is explored in detail in Pazderka and Stegemann (2005).

3. "New Trade Battle Looms Over Drugs." 2004 (February 4). Financial Times: 5.

4. Inter-country differences remain with respect to such matters as protection of data originating from clinical trials, "evergreening" of patents, and flexibility in parallel imports and compulsory licensing (especially in developing countries). The speed of introduction of generic drugs is affected by legislative provisions permitting the use of patented product for testing purposes to produce and stockpile generic drugs before patent expiry. Some of these provisions have been dealt with by the WTO (Howse 2000).

\section{REFERENCES}

Ginarte, J.C. and W.G. Park. 1997. "Determinants of Patent Rights: A Cross-National Study." Research Policy 26: 283-301.

Howse, R. 2000 (July). "The Canadian Generic Medicines Panel - A Dangerous Precedent in Dangerous Times." World Journal of Intellectual Property 3(4): 493-507.

Jacobzone, S. 2000. Pharmaceutical Policies in OECD Countries: Reconciling Social and Industrial Goals, Labour Market and Social Policy. Occasional Paper No. 40. Paris: Organisation for Economic Co-operation and Development.

"New Trade Battle Looms Over Drugs." 2004 (February 4). Financial Times: 5.

Park, W.G. 2001. "Intellectual Property and Patent Regimes." In Economic Freedom of the World: 2001 Annual Report. Vancouver: The Fraser Institute.

Patented Medicine Prices Review Board (PMPRB). 2006. Annual Report. Ottawa: Author.

Pazderka, B. and K. Stegemann. 2005. "Pharmaceutical Innovation As a Collective Action Problem. An Application of the Economic Theory of Alliances." Journal of World Intellectual Property 8(2): 157-91.

Pharmaceutical Research and Manufacturers of America (PhRMA). 2006. Pharmaceutical Industry Profile 2006. Washington, DC: Author.

Schiff, E. 1971. Industrialization without National Patents. The Netherlands, 1869-1912, Switzerland, 1850-1907. Princeton, NJ: Princeton University Press.

Zutshi, B.K. 1998. "Bringing TRIPS into the Multinational Trading System.” In J. Bhagwati and M. Hirsch, eds., The Uruguay Round and Beyond: Essays in Honor of Arthur Dunkel. Ann Arbor, MI: University of Michigan Press. 